\title{
Псевдомембранозний коліт - практичні аспекти діагностики і лікування (короткий огляд літератури)
}

\begin{abstract}
Частим ускладненням антибіотикотерапії є антибіотик-асоційована діарея, основним причинним фактором виникнення якої у стаціонарних хворих вважається C. difficile інфекція. Найважчим варіантом перебігу C. difficile інфекції є псевдомембранозний коліт.

Огляд літератури виконано за результатами пошуку в базах даних PubMed за ключовими словами “антибіотик-асоційована діарея”, “С. difficile інфекція”, “С. difficile-асоційований коліт”, “псевдомембранозний коліт” за період 2006-2016 рр.

На підставі короткого огляду літератури наведено особливості Clostridium difficile інфекції та основні фактори ризику виникнення Clostridium difficile коліту. Висвітлено типову клінічну симптоматику перебігу псевдомембранозного коліту. Окреслено труднощі діагностики та практичні аспекти застосування візуалізаційних методів - сигмоскопії, ультрасонографії. Акцентовано увагу на тяжких формах псевдомембранозного коліту, критеріях діагностики та особливостях лікування при рефрактерному перебігу захворювання. Наведено показання та принципи хірургічного лікування фульмінантного коліту. Окреслено основні принципи діагностики, лікування та профілактики згідно з сучасними міжнародними клінічними настановами.
\end{abstract}

Ключові слова: антибіотик-асоційована діарея; псевдомембранозний коліт; діагностика; стандарти лікування.

Антибіотик-асоційована діарея є частим побічним наслідком застосування антибактерійних препаратів і маніфестується від легкої форми до тяжкого перебігу захворювання, виникає у 3,2-29,0 \% пацієнтів [1]. В 70-х роках XX століття було встановлено етіологічне значення в патогенезі антибіотик-асоційованого коліту (АА-коліту) специфічного збудника - грам-позитивної анаеробної спороутворюючої палички Closridium difficile, яка $€$ поширеною в зовнішньому середовищі, особливо у грунті $[2,3,4]$. Цей мікроорганізм також є компонентом (0,01-0,001 \%) нормальної мікрофлори кишечника і може бути асимптоматично присутнім у 3-6 \% дорослих у популяції [2, 5]. Токсигенні штами C. difficile продукують сильні токсини ентеротоксин (токсин А) та цитотоксин (токсин B), які пошкоджують стінку кишечника і зумовлюють клінічні вияви захворювання [2, 3, 4, 5]. Тому збудник трактується як патоген, що становить загрозу здоров’ю людини і потребує негайної та агресивної реакції на нього [6]. Незважаючи на певні досягнення у лікуванні C. difficile інфекції, в останні роки спостерігається тенденція до збільшення частоти, тяжкості, летальності та кількості рецидивів захворювання [3, 7]. Термінологічно C. difficile інфекція залежно від тяжкості клінічного перебігу може визначатися як $C$. difficile діарея, C. difficile-асоційований коліт та псевдомембранозний коліт (Pseudomembranous Colitis), який є найбільш відомим варіантом цієї клостридіальної інфекції $[2,4,5,8]$. Водночас псевдомембранозний коліт (ПМК) є одним із найтяжчих ускладнень антибіотикотерапії - при відсутності лікування летальність становить 15-30 \% [5], а у пацієнтів старшого віку та при фульмінантних і ускладнених формах перебігу захворювання сягає 40-60 \% $[2,5,8]$ і навіть $71 \%$ при вимушеному хірургічному лікуванні [9]. Саме ці тяжкі та ускладнені форми C. difficile-асоційованого коліту в більшості випадків зумовлюють значні діагностично-лікувальні труднощі і є причинами несприятливих результатів лікування.

Мета роботи: на підставі короткого огляду літератури акцентувати увагу на труднощах діагностики та лікування тяжкого псевдомембранозного коліту (ПМК).

Літературний пошук в базах даних PubMed здійснено за ключовими словами " $C$. difficile інфекція”, “C. difficile-асоційований коліт”, “псевдомембранозний коліт” за період 2006-2016 рр. Вибірку публікацій здійснено з акцентом на клінічну маніфестацію псевдомембранозного коліту, інформативність методів обстеження та особливості лікування залежно від перебігу захворювання.

В останні роки спостерігається прогресуюче збільшення кількості випадків антибіотик-асоційованої діареї (АА-діареї), яка виникає у 10-15 \% госпіталізованих пацієнтів при системному застосуванні антибактерійних засобів [5]. Однією із основних причин виникнення АА-діареї у госпіталізованих пацієнтів вважають C. difficile інфекція $[7,8]$, частота виникнення якої в стаціонарі перевищує $1 \%$ із ризиком летального наслідку на рівні 10 \% [10]. Окрім того, цей патоген трактується од- 
ним із найчастіших чинників нозокоміальних інфекцій і набуває в останні роки характеру епідемії $[2,3,4]$. Необхідно також вказати, що коліт, зумовлений C. difficile, має різні клінічні варіанти перебігу - від неускладненої діареї до загрозливих для життя псевдомембранозного коліту і токсичного мегаколону із потенційним розвитком тяжких ускладнень [2, 8]. Факторами ризику виникнення АА-діареї є режим антибіотикотерапії, похилий вік пацієнтів, жіноча стать, тривалість госпіталізації, абдомінальні хірургічні втручання, назоінтестинальний тюбаж, хіміо-/променева терапія, ендоскопія, імунні розлади, фонові захворювання (діабет, запальні захворювання кишечника), застосування інгібіторів протонної помпи, нестероїдних протизапальних і протигрибкових засобів [1, $2,3,4,5,8,10]$. Варто зазначити, що у онкологічних пацієнтів частота виникнення клостридіальної діареї $є$ у 6 разів вища, ніж у інших госпіталізованих хворих [11]. До того ж, хіміотерапевтичні препарати спричиняють запально-некротичні зміни в кишечнику та анаеробні умови, що сприяють проліферації C. difficile, тоді як екстравазація протеїнів у просвіт кишки може гальмувати розпад та деградацію токсинів збудника [11].

АА-діарею можуть спровокувати всі групи антибіотиків. Тривале використання декількох антибіотиків, особливо широкого спектра із поганою кишковою абсорбцією чи високою жовчною екскрецією, спричинює зміни кишкової мікрофлори i, отже, може призвести до виникнення C. difficile інфекції $[2,5,10]$. Водночас ризик цього ускладнення не залежить від дози, кратності, способу введення антибіотика, можливий навіть його розвиток після однократного застосування препарату [5]. Найчастіше C. difficile інфекцію спричиняють цефалоспорини (особливо другого/третього/четвертого поколінь), фторхінолони, пеніциліни розширеної дії та кліндаміцин [2, 3, 5, 8].

Клінічна маніфестація ПМК може розвинутися у терміни від 1 до 5 тижнів від початку (або припинення) застосування антибактерійних препаратів, найчастіше - через 10-15 днів [5]. Діарея $\epsilon$ кардинальним симптомом хвороби і проявляється через 48-72 год після розвитку інфекції [2]. Загалом основними клінічними проявами є: діарея із водянистими випорожненнями (аж до профузних “холероподібних") із частотою від 4-5 до 20 разів на добу, абдомінальний (біль) та диспептичний (нудота, здуття) синдроми, ознаки загальної інтоксикації із лейкоцитозом (до $30 \times 10 \%$ л) та гіпоальбумінемією [5]. Діагноз АА-діареї повинен бути розглянутий у кожного пацієнта із проявами діареї в терміни аж до 8 тижнів після закінчення антимікробної терапії [10]. Ризик C. difficile ін- фекції підвищується при фоновій імуносупресії (включно злоякісні захворювання, хіміотерапію, лікування стероїдами, трансплантацію органів i цироз), тому такі пацієнти при виникненні діареї повинні бути відповідно обстежені [4]. Водночас при недостатній настороженості або інформованості клініцистів дебют захворювання може трактуватися як аліментарна чи неспецифічна діарея, що зумовлює помилки в ініціальному лікуванні та спричинити прогресування процесу аж до тяжких чи ускладнених форм ПМК.

Для виявлення ПМК важливими є клінічна інформація, лабораторні дані, візуалізаційні методи та ендоскопічна діагностика. Наявність АА-діареї може бути стверджена при зміні нормальних випорожнень на 3-кратні чи рідкі випорожнення принаймні протягом двох наступних діб у пацієнтів, яким проводили системну антибактерійну терапію при виключенні інших причин кишкових розладів (інфекційного ентериту або коліту, хронічних запальних захворювань кишечнику, ішемічного коліту) $[1,2,9]$. Визначальним у верифікації діагнозу C. difficile інфекції $є$ ідентифікація токсинів А і В у пробах випорожнень [3, $13,14]$. У найновіших рекомендаціях із лікування C. difficile інфекції у хірургічних хворих [13] вказується, що в імуноскомпроментованих пацієнтів, у т. ч. після хіміотерапії, при наявності діарейного синдрому завжди треба проводити лабораторне обстеження на цю інфекцію. На жаль, на сьогодні в практичних реаліях вітчизняної медицини специфічна ідентифікація C. difficile інфекції є малодоступною.

Для оцінки запального ураження кишечника (коліту) можна застосовувати ультрасонографію (УСГ). Результати обстеження дозволяють опосередковано ствердити ступінь запального ураження стінки кишки для діагностики C. difficile коліту в ускладнених випадках. Наявність ПМК можна запідозрити при виявленні потовщення стінок кишки, набряку клітковини параколон, вільної рідини в черевній порожнині, нашарувань фібрину на парієнтальній та вісцеральній очеревині, причому чутливість методу становить $95 \%$, специфічність $47 \%$, точність $84 \%$ [15]. Автори пропонують проводити УСГ у тяжкої категорії пацієнтів і для динамічного контролю за перебігом захворювання. Застосування комп'ютерної томографії органів черевної порожнини рекомендується для пацієнтів із тяжким ускладненим перебігом ПМК $[4,13]$.

Методом прямої візуалізації ПМК є ендоскопічне обстеження товстої кишки, яке дозволяє виявити патогномонічні ознаки - специфічні припідняті над рівнем набряклої та гіперемійованої 
(кровоточивої при контакті) слизової жовто-білі бляшки (“псевдомембрани”) від 2 до 15 мм, які у тяжких випадках можуть мати зливний характер із вогнищами некрозів [2, 3, 5, 8]. Водночас відсутність мембран не виключає наявності C. difficile інфекції, і навпаки - виявлення ендоскопічних ознак ПМК є достатнім аргументом для обгрунтування клостридіального ґенезу захворювання [9]. У випадках ПМК сигмоскопія гнучким ендоскопом більш інформативна при ствердженні діагнозу порівняно із обстеженням калу на токсини А, враховуючи ймовірність негативного результату лабораторних обстежень [8, 14]. Проте відсутня пряма кореляція між ендоскопічною симптоматикою і тяжкістю хвороби [9]. У ранній період захворювання, обстеження навіть у виконанні досвідченого ендоскопіста, повинно бути застосоване з обмеженнями (враховуючи ризик перфорації) і за показаннями - для пацієнтів із тяжким колітом невстановленої етіології при негативних лабораторних тестах, при необхідності швидкого встановлення діагнозу, неефективності етіотропної терапії, атиповому перебізі ПМК [2].

3 клінічної точки зору для вибору специфічного лікування доцільнем є розмежування коліту за тяжкістю на 3 форми. При легкій формі наявна діарея (до 4-5 разів на добу) при відсутності іншої симптоматики. Середня форма тяжкості ПМК проявляється багаторазовою діареєю (до 1015 разів на добу), лейкоцитозом (до $15 \times 10 \%$ л), абдомінальним синдромом та інтоксикацією [4]. Загальноприйнятих критеріїв тяжкої форми ПМК немає, хоча в основному вважають, що такий варіант перебігу маніфестується виснажливою діареєю (до 15-20 разів на добу) при домінуванні системних проявів: ментальних розладів, наростаючої інтоксикації із високим лейкоцитозом (понад $15 \times 10 \%$ л), гарячкою, лактатацидозом; нерідко спостерігаються гіпоальбумінемія, гіповолемія та асцит [2, 4, 7, 9].

Необхідним є своєчасне виявлення ускладнених форм ПМК $[4,7]$. До них відносять випадки із гіпотензією або шоком, необхідністю госпіталізації у відділення інтенсивної терапії, органною недостатністю, кількістю лейкоцитів у периферійній крові понад $35 \times 10^{9}$ /л або менше $2 \times 10^{9}$ /л [4, 7], а також ознаками перитоніту, кишкової непрохідності, токсичного мегаколону, перфорації товстої кишки чи випадки із смертельним наслідком [9]. В якості предикторів ускладненого перебігу захворювання пропонуються лейкоцитоз і ниркова недостатність (наявні в момент підтвердження діагнозу ПМК), а також еозинопенія та низький рівень альбуміну крові $[4,9]$. Гіпоальбумінемія при госпіталізації є індикатором недостатнього живлення і метаболічного статусу пацієнта, тоді як зменшення рівня альбуміну протягом лікування свідчить про тяжку форму ентеропатії, яка загалом є проявом ПМК. Водночас власне гіпоальбумінемія може спричинити імунні порушення і сповільнити відповідь на лікування $[4,8,11]$.

На сьогодні існують загальноприйняті чіткі клінічні рекомендації щодо лікування C. difficile інфекції [4, 9, 13]. Основними антибактерійними препаратами є метронідазол і ванкоміцин [2, 4, 7, 9,13]. Для вибору стартової етіотропної терапії ПМК необхідним є розмежування захворювання за тяажкістю $[7,9]$. Як препарат вибору при легкому та середньої тяжкості перебігу першого епізоду, а також першому рецидиві рекомендованим є прийом метронідазолу в дозі 500 мг 3 рази на добу - протягом 10-14 днів [2, 4, 7, 9, 13]. Ванкоміцин є препаратом вибору при тяжкому або ускладненому перебізі C. difficile інфекції, неефективності або неможливості терапії метронідазолом, а також другому і подальших рецидивах захворювання. Рекомендоване ентеральне приймання ванкоміцину по 125 мг 4 рази на добу $[4,7,9,13]$. Призначення ванкоміцину у знижених дозах у пульс-режимі протягом 3-4 тижнів після стандартного курсу терапії первинного епізоду C. difficile інфекції може зменшити частоту рецидивів захворювання [3, 4, 5, 9]. Надходження етіотропного препарату через день або кожен третій день дозволяє у дні, вільні від лікування, прорости спорам C. difficile у вегетативні (активні) форми, які згодом потраплять під експозицію антибіотика [12]. В якості альтернативи рекомендоване призначення пробіотиків протягом двох чи більше тижнів [7].

Схеми для тяжкого ускладненого чи рефрактерного коліту передбачають поєднання ванкоміцину (ентерально) і метронідазолу (довенно) [2, 3, 4, 5] або призначення фідаксоміцину [9], при ускладнених колітах із неможливістю ентерального приймання препаратів - додатково застосовують введення ванкоміцину у клізмі чи через назогастральний зонд [3, 4, 5, 9]. У комплексі патогенетичного лікування для зв'язування токсинів можна застосовувати ентеросорбенти (ентеросгель) та препарати цитопротективної дії (діосмектит) [5]. До ознак, які свідчать про ефективність лікування, відносять клінічний ефект (зменшення частоти і зміна характеру випорожнень) і поліпшення клініко-лабораторних та радіологічних критеріїв тяжкості захворювання при відсутності нових симптомів тяжкого процесу. Оцінка відповіді на лікування проводиться після 3 діб (для ме- 
тронідазолу 3-5 діб) етіотропної терапії [4, 9]. У пацієнтів із онкологічною патологією значно пізніше проявляється клінічний ефект від лікування при вдвічі довших середніх термінах припинення діарейного синдрому [11].

Призначення пробіотиків для профілактики і лікування ПМК є дискусійним, а результати мета-аналізів свідчать, що лише Lactobacillus rhamnos GG i Saccharomyces boulardii можуть бути ефективними [2, 4, 5, 7, 10], хоча у тяжких клінічних випадках можуть призвести до бактеріємії/фунгемії або сепсису [2, 9]. В актуальних клінічних настановах вказано, що доказова база щодо ефективності застосування пробіотиків при C. difficile інфекції є недостатньою [4, 9], або вони можуть бути призначені як додаткова терапія у імунокомпетентних пацієнтів [13].

Рецидиви $€$ найчастішим ускладненням CDасоційованих інфекцій і розвиваються у 10-25 \% пацієнтів протягом 30 діб, незважаючи на застосоване лікування $[2,3,5,7,8,10,11]$. Пацієнти можуть мати багаторазові рецидиви (до 14) [5], які виникають у термін до 2 місяців після одужання, причому після перенесеного першого рецидиву ризик повторних рецидивів зростає до 40-65 \% $[3,7,10]$. Факторами ризику виникнення рецидиву вважають похилий вік, супутні захворювання, приймання антибіотиків після підтвердження діагнозу Clostridium difficile інфекції, попереднє застосування фторхінолонів, імунні розлади, призначення інгібіторів протонної помпи, хронічна ниркова недостатність [10].

При багатократних рецидивах клостридіального коліту, рефрактерного до лікування антибактерійними препаратами, додатково до антибіотикотерапії в актуальних клінічних настановах пропонують виконувати трансплантацію кишкової мікробіоти (англ. fecal microbiota transplant) [ 4, 9 ].

Хірургічне лікування показане пацієнтам із фульмінантним колітом при неефективності лі-

\section{СПИСОК ЛІТЕРАТУРИ}

1. Prevalence and management of antibiotic associated diarrhea in general hospitals / Monique M. Elseviers, Yoleen Van Camp, Sander Nayaer [et al.] // BMC Infectious Diseases. - 2015. № 15 (129). - P. 1-9.

2. Clostridium difficile: epidemiology, diagnostic and therapeutic possibilities - a systematic review / M. Kazanowski, S. Smolarek, F. Kinnarney, Z. Grzebieniak // Tech. Coloproctol. - 2014. - № 18 (3). - P. 223-232.

3. Зінчук О. М. Сучасні аспекти Clostridium difficile-інфекції / О. М. Зінчук, О. О. Зубач, Г. Л. Столяр // Інфекційні хвороби. - 2014. - № 3.- С. 5-12.

4. Guidelines for Diagnosis, Treatment, and Prevention of Clostridium difficile Infections / Christina M. Surawicz, Lawrence кування і прогресуванні системної інтоксикації. Тотальну колектомію виконують у випадках перфорації товстої кишки, розвитку токсичного мегаколону чи тяжкої кишкової непрохідності. Xiрургічне лікування найкраще виконувати до розвитку тяжкого коліту. Зокрема, рівень лактату сироватки крові може бути маркером тяжкості (операційне втручання виконувати до перевищення показника у 5 ммоль/л). Перспективною альтернативою колектомії може бути відвідна петлева ілеостомія ( англ. diverting loop ileostomy) із антеградним лаважем товстої кишки (ванкоміцин) в поєднанні із антибактерійною терапією (внутрішньовенно метронідазол) [ 9 ].

У стратегії зниження ризику виникнення Clostridium difficile інфекції і, відповідно, псевдомембранозного коліту, виняткову увагу приділяють уникненню необгрунтованого призначення системної антибактерійної терапії [4, 5, 6, 13]. При необхідності потужної антибіотикотерапії для попередження ПМК доцільною та ефективною може бути раціоналізація схем та режимів застосування антибактерійних препаратів. Практичні підходи засновані на тому, що вказане ускладнення зазвичай $є$ внутрішньолікарняною інфекцією, тому важливими є заходи попередження колонізації Clostridium difficile госпіталізованих пацієнтів $[4,9,13]$. Значимим компонентом профілактики, вчасного виявлення і запобігання рецидивів цього захворювання повинна стати адекватна інформованість клініцистів $[3,5,10]$.

Висновки. 1. Clostridium difficile коліт - це потенційно тяжке ускладнення антибіотикотерапії. 2. Псевдомембранозний коліт маніфестується виснажливою діареєю та вираженим інтоксикаційним синдромом. 3. Дотримання сучасних діагностично-лікувальних підходів необхідне для своєчасного виявлення цього ускладнення та запобігання розвитку тяжких форм псевдомембранозного коліту.

J. Brandt, David G. Binion [et al.] // Am. J. Gastroenterol. - 2013. - № 108. - P. 478-498.

5. Посохова К. А. Антибіотик-асоційоване ураження кишечнику / К. А. Посохова // Інфекційні хвороби. - 2010. № 4. - C. 69-80.

6. Wenzler E. The antimicrobial stewardship approach to combating clostridium difficile / E. Wenzler, Surafel G. Mulugeta, Larry H. Danziger // Antibiotics. - 2015. - № 4. - P. 198-215.

7. Al-Jashaami Layth S. Management of Clostridium difficile Infection Layth S. Al-Jashaami, Herbert L. DuPont // Gastroenterology \& Hepatology. - 2016. - Vol. 12, Issue 10. P. 609-616.

8. Risk factors for severity and relapse of pseudomembranous 
colitis in an elderly population / M. Moshkowitz, E. Ben-Baruch, Z. Kline [et al.] // Colorectal Disease. - 2006. - № 9. - P. 173177.

9. Debast S. B. European Society of Clinical Microbiology and Infectious Diseases: update of the treatment guidance document for Clostridium difficile infection / S. B. Debast, M. P. Bauer, E. J. Kuijper // Clinical Microbiology and Infection. - 2014. Vol. 20, Suppl. 2. - P. 1-26.

10. Risk factors for recurrent Clostridium difficile infection: a systematic review and meta-analysis / Abhishek Deshpande, Vinay Pasupuleti, Priyaleela Thota [et al.] // Infection Control \& Hospital Epidemiology. - 2015. - Vol. 36, Issue 04. - P. 452-460. 11. Resolution of Clostridium difficile-associated diarrhea in patients with cancer treated with Fidaxomicin or Vancomycin / Oliver A. Cornely, Mark A. Miller, Bruno Fantin [et al.] // Journal of Clinical Oncology. - 2013. - Vol. 31. - № 19. - P. 2493-2499.
12. Bonasera R. J. Relapsing Clostridium Difficile Colitis / R. J. Bonasera, J. K. Kramer, Sammy Ho // Practical Gastroenterology. - 2004. - P. 78-80.

13. WSES guidelines for management of Clostridium difficile infection in surgical patients / Massimo Sartelli, Mark A. Malangoni, Fikri M. Abu-Zidan [et al.] // World Journal of Emergency Surgery. - 2015. - № 10 (38). - P. 1-23.

14. European Society of Clinical Microbiology and Infectious Diseases: update of the diagnostic guidance document for Clostridium difficile infection / M. J. T. Crobach, T. Planche, C. Eckert [et al.] // Clinical Microbiology and Infection. - 2016. № 22. - P. S63-S81.

15. Возможности ультразвукового исследования в диагностике псевдомембранозного колита у хирургических больных / О. А. Алексеечкина, Э. Я. Дубров, Е. С. Владимирова [и др.] // РЖГГК. - 2012. - № 2. - С. 29-35.

\section{REFERENCES}

1. Elseviers, M.M., Van Camp, Y., Nayaert, S., Dure, K., Annemans, L., Tanghe, A., \& Vermeersch, S. (2015). Prevalence and management of antibiotic associated diarrhea in general hospitals. BMC Infectious Diseases, 15 (129), 1-9.

2. Kazanowski, M., Smolarek, S., Kinnarney, F., \& Grzebieniak, Z. (2014). Clostridium difficile: epidemiology, diagnostic and therapeutic possibilities - a systematic review. Tech. Coloproctol., 18 (3), 223-232.

3. Zinchuk, O.M., Zubach, O.O., \& Stoliar, H.L. (2014). Suchasni aspekty Clostridium difficile-infekcii [Modern aspects of Clostridium difficile-infection]. Infektsiini khvoroby - Infection Deseases, 3, 5-12 [in Ukrainian].

4. Surawicz, C.M., Brandt, L.J., Binion, D.G., Ananthakrishnan, A.N., Curry, S.R., Gilligan, P.H., \& McFarland, L.V. (2013). Guidelines for diagnosis, treatment, and prevention of Clostridium difficile infections. Am. J. Gastroenterol., 108, 478-498.

5. Posokhova, K.A. (2010). Antybiotyk-asotsiiovane urazhennia kyshechnyku [Antibiotic-asociated defeat of intestine]. Infektsiini khvoroby - Infection Diseases, 4, 69-80 [in Ukrainian].

6. Wenzler, E., Mulugeta, S.G., \& Danziger, L.H. (2015). The antimicrobial stewardship approach to combating Clostridium difficile. Antibiotics, 4, 198-215.

7. Al-Jashaami, L.S., \& DuPont, H.L. (2016). Management of Clostridium difficile Infection. Gastroenterology \& Hepatology, 12 (10), 609-616.

8. Moshkowitz, M., Ben-Baruch, E., Kline, Z., Shimoni, Z., Niven, M., \& Konikoff, F. (2006). Risk factors for severity and relapse of pseudomembranous colitis in an elderly population. Colorectal Disease, 9, 173-177.

9. Debast, S.B., Bauer, M.P., \& Kuijper, E.J. (2014). European Society of Clinical Microbiology and Infectious Diseases: update

of the treatment guidance document for Clostridium difficile infection. Clinical Microbiology and Infection, 20 (2), 1-26.

10. Deshpande, A., Pasupuleti, V., Thota. P., Pant, C., Rolston, D.K., Hernandez, A.V., \& Donskey, C.J. (2015). Risk factors for recurrent Clostridium difficile infection: a systematic review and meta-analysis. Infection Control \& Hospital Epidemiology, 36 (04), 452-460.

11. Cornely, O.A., Miller, M.A., Fantin, B., Mullane, K., Kean, Y., \& Gorbach, S. (2013). Resolution of Clostridium difficile-associated diarrhea in patients with cancer treated with Fidaxomicin or Vancomycin. Journal of Clinical Oncology, 31 (19), 2493-2499.

12. Bonasera, R.J., Kramer, J.K., \& Ho, S. (2004). Relapsing Clostridium difficile colitis. Practical Gastroenterology, 78-80.

13. Sartelli, M., Malangoni, M.A., Abu-Zidan, F. M., Griffiths, E.A., Bella, S.D., McFarland, L.V., \& Eltringham, I. (2015). WSES guidelines for management of Clostridium difficile infection in surgical patients. World Journal of Emergency Surgery, 10 (38), 1-23.

14. Crobach, M.J.T., Planche, T., Eckert, C., Barbut, F., Terveer, E.M., Dekkers, O.M., \& Wilcox, M.H. (2016). European Society of Clinical Microbiology and Infectious Diseases: update of the diagnostic guidance document for Clostridium difficile infection. Clinical Microbiology and Infection, 22, 63-81.

15. Alekseyechkina, O.A., Dubrov, E.Ya., Vladimirova, Ye.S., Pinchuk, T.P.,\&Titova, G.P.(2012). Vozmozhnostiultrazvukovogo issledovaniya $\mathrm{v}$ diagnostike psevdomembranoznogo kolita u hirurgicheskikh bolnykh [Potential of ultrasound investigation in diagnostics of pseudomembranous colitis in surgical patients]. RZhGGK - Russian Journal of Gastroenterology, Hepatology and Coloproctology, 2, 29-35 [in Russian].

Отримано 21.08.2017 


\author{
YU. S. LYSIUK, L. M. KOHUT, D. L. ROMANCHAK, O. V. VOITOVYCH
}

Danylo Halytskyi Lviv National Medical University

\title{
PSEUDOMEMBRANOUS COLITIS - THE PRACTICAL ASPECTS OF DIAGNOSIS AND TREATMENT (BRIEF LITERATURE REVIEW)
}

\begin{abstract}
A frequent complication of antibiotic therapy is antibiotic-associated diarrhea. It is considered to be mainly caused by C. difficile infection in hospitalized patients. Pseudomembranous colitis is the most severe clinical cause of C. difficile infection.

The literature review was carried out according to the search results in the database of PubMed by key words "antibiotic-associated diarrhea", "C. difficile infection", "C. difficile-colitis", pseudomembranous colitis" within the period of 2006-2016.

The brief literature review presents the peculiarities of C. difficile infection and the main causes of Clostridium difficile colitis occurrence. Typical clinical symptoms of pseudomembranous colitis are analyzed. The diagnostics difficulties and practical aspects of visualization methods (flexible sigmoidoscopy and ultrasonography) used are also the subject of this article. The attention is drawn to the specifics of a clinical course of severe form of pseudomembranous colitis, the diagnostics criteria and treatment peculiarities of refractory course of disease. The indications and principles of surgical treatment of fulminant colitis are presented. Main principles of diagnosis, treatment and prevention according to international clinical guidelines are described.
\end{abstract}

Key words: antibiotic-associated diarrhea; pseudomembranous colitis; diagnostics; guidelines of treatment.

Ю. С. ЛЫСЮК, Л. Н. КОГУТ, Д. Л. РОМАНЧАК, Е. В. ВОЙТОВИЧ

Львовский национальный медицинский университет имени Данила Галицкого

\section{ПСЕВДОМЕМБРАНОЗНЫЙ КОЛИТ - ПРАКТИЧЕСКИЕ АСПЕКТЫ ДИАГНОСТИКИ И .ЛЕЧЕНИЯ (КРАТКИЙ ОБЗОР .ЛИТЕРАТУРЫ)}

\begin{abstract}
Частым осложнением антибиотикотерапии является антибиотик-ассоциированная диарея, основным причинным фактором возникновения которой у стационарных больных считается $C$. difficile инфекция. Самым тяжелым вариантом течения C. difficile инфекции является псевдомембранозный колит.

Обзор литературы выполнен за результатами поиска в базах данных PubMed по ключевым словам “антибиотик-ассоциированная диарея”, “С. difficile инфекция”, “С. difficile-колит”, “псевдомембранозный колит” за период 2006-2016 гг.

На основании краткого обзора литературы поданы особенности Clostridium difficile инфекции и основные факторы риска возникновения Clostridium difficile колита. Приведено типичную клиническую симптоматику течения псевдомембранозного колита. Очерчены трудности диагностики и практические аспекты применения визуализационных методов - сигмоскопии, ультрасонографии. Акцентировано внимание на клиническом течение тяжелых форм псевдомембранозного колита, критериях диагностики и особенностях лечения при рефрактерном течении заболевания. Наведены показания и принципы хирургического лечения при фульминантном колите. Поданы основные принципы диагностики, лечения и профилактики согласно современных международных клинических рекомендаций.
\end{abstract}

Ключевые слова: антибиотик-ассоциированная диарея; псевдомембранозный колит; диагностика; стандарты лечения. 